WwW.ijbpas.com

\title{
EFFECT OF PUNARNAVADI GUGGULU IN THE MANAGEMENT OF PREMENSTRUAL SYNDROME - A SINGLE CASE STUDY
}

\section{RATHORE M $^{1}$ AND KARKARE $\mathbf{M}^{2 *}$}

1: PG Scholar, Department of Prasuti Tantra Evum Stri Roga, Parul Institute of Ayurveda, Parul University, Vadodara, Gujarat, India

2: Professor \& Head of Department, Department of Prasuti Tantra Evum Stri Roga, Parul Institute of Ayurveda, Parul University, Vadodara, Gujarat, India

*Corresponding Author: Manjusha Karkare: E Mail: mrkarkare@gmail.com Received 12 ${ }^{\text {th }}$ Dec. 2021; Revised $14^{\text {th }}$ Jan. 2022; Accepted $7^{\text {th }}$ Feb. 2022; Available online $5^{\text {th }}$ March. 2022 https://doi.org/10.31032/IJBPAS/2022/11.3.1001

\begin{abstract}
Premenstrual Syndrome is an entity about which people are not much aware. No too much studies have been yet done for this particular condition. Women deals with this condition very casually. Menstruation plays an important role in women's reproductive life to get a healthy progeny. Any deviation from normalcy, indicative of any abnormality in the reproductive cycle causes a great impact on the quality of a woman's physical, emotional, social and reproductive life. Premenstrual Syndrome is the cyclical occurance of certain symptoms just prior to menses in the luteal phase of the cycle, which get resolved spontaneously on the onset of menses or just after 2 to 3 days of menses. The symptoms do not reappear within the next 13 days or before the luteal phase. A wide range of symptoms occurs in PMS. In this study "Punarnavadi Guggulu" was given for Premenstrual Syndrome, which is a combination of mainly 5 drugs namely Punarnava, Devdaru, Guduchi, Haritaki, Guggulu, and Erand Tail as bhawana dravya. Diagnosis of PMS was confirmed by the complaints described by the patients and scoring was done with the help of a screening tool (based on PMTS-OR scale). Assessment was done before treatment and after the completion of observational cycle. The patient had a pre-intervention score of 40 which was a severe grade of PMS. After the intervention and the observation period, she had a score of 0 corresponding to doubtful or absent PMS with $100 \%$ relief. The patient thus had complete
\end{abstract}


cure in PMS. In present study, it was observed that Punarnavadi Guggulu has provided significant relief in all the symptoms of Premenstrual Syndrome.

\section{Keywords: Punarnavadi Guggulu, PMS, Premenstrual Syndrome, Severity, PMDD, Emotional Symptoms, Cognitive Symptoms. PMTS-OR scale}

\section{INTRODUCTION}

Premenstrual syndrome is a psycho-neuroendocrine disorder of unknown etiology, noticed just prior to menstruation. A large number of symptoms occurs cyclically and regularly during the luteal phase of each ovulatory menstrual cycle. Symptoms are severe enough in disturbing the day to day life of the woman or she may requires medical help. There must be symptom-free period in the cycle, specifically after menstrual phase and before luteal phase. Premenstrual dysphoric disorder (PMDD) is a more severe form of PMS, when these symptoms starts disrupting daily functioning of the woman. More than 200 symptoms are included in PMS.

The cause of PMS is currently not clearly known. Several hypotheses have been put forward to explain this entity. Some current theories which explain PMS causes include:

A) Low level of endorphins in bloodEndorphins, which are feel good hormones, contribute to the feeling that is happiness and regulates the mood. The level of this 'feel good' hormone drops to the lower level during luteal phase of menstrual cycle. Hence because of that low beta endorphins, PMS symptoms occurs.

B) Deficiency of Serotonin - Serotonin is a chemical present in brain that regulates many functions like mood and sensitivity to pain.

In support to this theory, role of serotonin in the pathophysiology of PMDD has been shown in the research investigations by using several experimental models. During the premenstrual phase, patients with PMDD have low whole blood serotonin level and low platelet serotonin uptake that controls without PMDD

C) Nutrition - Magnesium and calcium deficiency have also been postulated as the cause of PMS because supplementation with these minerals have been shown to improve some PMS symptoms.

D) Prostaglandins- According to another theory, Prostaglandin which is an inflammatory substance, is produced in the areas where PMS symptoms originates like in breast, brain, reproductive tract, kidney and gastrointestinal tract, which may play a role in symptoms like cramping, breast tenderness, constipation or diarrhoea. 
E) One of the theories under research include alteration in gamma-aminobutyric acid i.e. GABA system and hypoprolactinemia. Gama-aminobutyric acid (GABA) suppresses the anxiety level in the brain. Medications that are GABA agonist, are effective ${ }^{4}$.

\section{PROPOSED AYURVEDIC SAMPRAPATI:}

Due to nidana atisevana (improper lifestyle, junk food, stress etc) vatadi doshas get vitiated, causes specifically kapha vata prakopa (accumulation of kleda, pratiloma gati of vata) the accumulated kapha dosha results into symptoms such as swelling of extremities, excessive sleep, vata causes backache, vata and kapha together causes bloating of abdomen, painful and tender breast, feeling of heaviness in breast, headache. Vitiated vata and kapha due to the pratiloma gati, affects the Manas giving rise to Manasika Lakshanas like depression, anxiety, confusion (due to aavaran janya samprapti), angry outburst etc and thus causing Premenstrual Syndrome.

$$
\text { Currently available }
$$

research shows very few studies of this entity in Ayurveda. Efforts have been made to understand the problem on the basis of doshic imbalance. Primarily an imbalance of Vata dosha resulting from bad lifestyle choices is seen to at the root of this pathology. Vimudha Vaata especially Apana exerts an influence on the other
Vayus of the body, thereby disrupting their functions. Simultaneous accumulation of Kleda and the organ or system having a Kha Vaigunya then expresses the symptoms related to PMS. Punarnavadi Guggulu was choosen to deal with the problem because of its Vata Shamana and Shothaghna properties. It is also indicated in Kapha Amayas as per Bhaishajya Ratnawali .

\section{ESTIMATED SAMPRAPATI GHATAK:}

- Dosha: Tridosha specifically Kapha, Vata

- Dushya: Ras, Rakta, meda, udak

- Srotas: Rasavaha, Artavavaha, manovaha

- Marga: Abhyantar

- Mahabhuta: Jala, vayu

- Udbhavasthana: Ama-Pakvashaya

- Vyaktasthana: Sarva sharir, Manah

\section{CASE REPORT:}

\section{CHIEF COMPLAINTS WITH DURATION}

Abdominal Bloating, Tension, Angry Outburst, Mood Swings, Crying Spell, Headache

All the symptoms were appearing 3-4 days prior to her menses till $1^{\text {st }}$ day of menses since 3 years.

\section{ASSOCIATED COMPLAINTS -}

Nausea and vomiting occasionally, Diarrhoea occassionally

which tend to resolve spontaneously after $1^{\text {st }}$ day of menses 


\section{HISTORY OF PRESENT ILLNESS -}

A 28-year-old female patient, came to O.P.D No. 104 of Parul Ayurveda Hospital, Dept of Stri Roga Evum Prasuti Tantra on 11/06/2021. She was alright 3 years back. She then started having cyclical episodes of Abdominal bloating, tension, angry outbursts, mood swings, crying spell, headache in the premenstrual phase. She also occasionally suffered from nausea, vomiting and diarrhoea which resolved spontaneously after $1^{\text {st }}$ day of menses. All the symptoms appeared 3-4 days prior to her menses and resolved spontaneously after the $1^{\text {st }}$ day of menses. The symptoms steadily increased in intensity over 3 years. As a result, her work and performance during that period was getting hampered and her overall progress was diminishing because of this problem. So, the patient approached PAH for Ayurvedic management.

\section{HISTORY OF PAST ILLNESS:}

Medical history - No H/o- DM, HTN, thyroid dysfunction

Surgical history - No surgical history
Drug history - No drug history

Family history - Mother is suffering with diabetes mellitus

Father is suffering with diabetes mellitus and hypercholesterolemia. Family history of PMS - No family history of PMS, neither in mother nor in siblings.

\section{Personal history:}

Marital history - married since 5 years, Occupation - Student, Food habit - food from outside usually fermented food from hotels, Diet - mixed , Appetite - good, Bowel - regular, Micturition - 4-5 times/day \& 1 time/night, Sleep - sound sleep of 6-7 hours/night, Habits - Tea intake 2 times/day, Other - occasional suppression of urge for micturition for 1-2 hrs, food from outside usually fermented food from hotels, Sedentary lifestyle Absence of Physical Excersizes, Inadequate Physical Activities, Day sleeping, Stress

\section{MENSTRUAL HISTORY:}

Menarche -16 years

LMP - 26/05/2021

Previous LMP - 24/04/2021

\begin{tabular}{|c|c|}
\hline Parameters & Menstrual history \\
\hline 1. Regularity & Regular \\
\hline 2. Quantity & 3-4 pads/day \\
\hline 3. Consistency & Normal \\
\hline 4. Smell & No foul smell \\
\hline 5. Duration & 4-5 days \\
\hline 6. Interval & 32 -34 days \\
\hline 7. Pain & Mild pain + \\
\hline 8. Colour & Reddish \\
\hline
\end{tabular}




\section{OBSTETRIC HISTORY:}

Marital life - 5 yrs

Active marital life -5 yrs

- Parity - 1, Abortion - 0, Live - 1, Death -0

- Nature of delivery - FTND at hospital

- Uneventful

CONTRACEPTIVE HISTORY: Condom use and Calender method.

\section{ON EXAMINATION:}

- General condition - good

- Pulse rate -76 bpm

- B.P - 110/70 mm Hg

- R.R - 18/min

- H.R - 76 bpm

- Height - $155 \mathrm{~cm}$, Weight - $53 \mathrm{~kg}$, BMI - 22.1

\section{SYSTEMIC EXAMINATION:}

- Respiratory system: B/L chest clear, Air Entry Bilaterally Equal

- Cardiovascular system: S1 S2 clear, heard

- CNS: Patient is conscious and well oriented. All superficial reflexes are intact.
- GIT: Soft abdomen, bowel sound heard, no pain \& tenderness, TL scar present

\section{PER SPECULUM EXAMINATION:}

- Cervix healthy

- No any kind of discharge was present

- Foul smell - absent

\section{PER VAGINAL EXAMINATION:}

- Uterus anteverted, anteflexed, normal size

- Freely mobile

- Fornices non-tender

\section{INVESTIGATIONS:}

Done on 17/06/2021 - (Before treatment) CBC: $\mathrm{Hb}-11.3 \mathrm{~g} / \mathrm{dl}$, TLC Count $8100 / \mathrm{cmm}$, Platelet count $-167000 / \mathrm{cmm}$ USG (Abdomen-Pelvis) - Bladder distended, uterus- normal in size, B/L ovaries normal in size No any significant abnormality detected. (To rule out pelvic pathology)

\section{ASHTAVIDHA PARIKSHA:}

\begin{tabular}{|c|c|c|}
\hline 1. & Nadi & Vata-pitta \\
\hline 2. & Mala & Saama, Samhat \\
\hline 3. & Mutra & Prakrita \\
\hline 4. & Jivha & Niraama \\
\hline 5. & Shabda & Spashta \\
\hline 6. & Sparsha & Anushna sheeta \\
\hline 7. & Druk & Samyak \\
\hline 8. & Akruti & Madhyama \\
\hline
\end{tabular}


DASHVIDHA PARIKSHA:

\begin{tabular}{|l|l|l|}
\hline 1. & Prakruti & Pitta kapha \\
\hline 2. & Vikruti & Kapha \\
\hline 3. & Sara & Madhyama \\
\hline 4. & Samhanana & Madhyama \\
\hline 5. & Pramana & Madhyama \\
\hline 6. & Satmya & Sarvarasa \\
\hline 7. & Satva & Madhyama \\
\hline 8. & Vaya & Madhyama \\
\hline 9. & Vyayamshakti & Madhyama \\
\hline 10. & Aharashakti & Madhyama \\
\hline
\end{tabular}

\section{ASSESSMENT CRITERIA ${ }^{13}$ :}

\section{PMTS-OR}

(PREMENSTRUAL TENSION SYNDROME- OBSERVER RATING SCALE)

\section{Observations}

\begin{tabular}{|c|c|c|c|c|}
\hline Symptoms & $\begin{array}{l}\text { Baseline } \\
\text { Scoring }\end{array}$ & $\begin{array}{c}\mathbf{1}^{\text {st }} \text { follow up } \\
\text { Scoring } \\
\text { (with } \\
\text { treatment) }\end{array}$ & $\begin{array}{c}2^{\text {nd }} \text { follow up } \\
\text { Scoring } \\
\text { (with } \\
\text { treatment) }\end{array}$ & $\begin{array}{c}3^{\text {rd }} \text { follow up } \\
\text { Scoring (without } \\
\text { treatment) }\end{array}$ \\
\hline & $\begin{array}{c}\text { BP }-110 / 70 \\
\text { Pulse }-76 \\
\text { Temp. }-97 \\
\text { RR - 18 }\end{array}$ & $\begin{array}{c}\text { BP }-110 / 78 \\
\text { Pulse }-78 \\
\text { Temp. - 97.4 } \\
\text { RR - 20 }\end{array}$ & $\begin{array}{c}\text { BP }-110 / 70 \\
\text { Pulse }-76 \\
\text { Temp. }-97 \\
\text { RR - 18 }\end{array}$ & $\begin{array}{c}\text { BP }-110 / 70 \\
\text { Pulse }-78 \\
\text { Temp. }-98 \\
\text { RR - 19 }\end{array}$ \\
\hline Date - & $11 / 06 / 2021$ & 29/07/2021 & $27 / 08 / 2021$ & 21/09/2021 \\
\hline LMP - & $26 / 05 / 2021$ & $24 / 07 / 2021$ & $23 / 08 / 2021$ & $20 / 09 / 2021$ \\
\hline 1. Depressed mood (0-4) & 3 & 2 & 1 & $\mathbf{0}$ \\
\hline 2. Anxiety/Tension (0-4) & 4 & 3 & 2 & $\mathbf{0}$ \\
\hline 3. Affective Lability (0-4) & 3 & 2 & 1 & $\mathbf{0}$ \\
\hline 4. Irritability/Hostility (0-4) & 3 & 2 & $\mathbf{0}$ & $\mathbf{0}$ \\
\hline $\begin{array}{l}\text { 5. Decreased Interest in Usual Activities (0- } \\
\text { 4) }\end{array}$ & 3 & 2 & $\mathbf{0}$ & $\mathbf{0}$ \\
\hline 6. Concentration Difficulties (0-4) & 4 & 2 & $\mathbf{0}$ & $\mathbf{0}$ \\
\hline 7. Marked Lack of Energy (0-4) & 3 & 2 & $\mathbf{0}$ & $\mathbf{0}$ \\
\hline 8. Eating Habits (0-2) & 2 & 2 & 2 & $\mathbf{0}$ \\
\hline 9. Sleeping Habits (0-2) & 1 & 1 & $\mathbf{0}$ & $\mathbf{0}$ \\
\hline 10. Overwhelmed (0-4) & 4 & 3 & 2 & $\mathbf{0}$ \\
\hline 11. Painful or Tender Breasts (0-4) & 4 & 4 & 3 & $\mathbf{0}$ \\
\hline $\begin{array}{l}\text { 12. Swelling of Abdomen, Ankles Or Fingers } \\
(0-4)\end{array}$ & $\mathbf{0}$ & $\mathbf{0}$ & $\mathbf{0}$ & $\mathbf{0}$ \\
\hline 13. Headache $(0-4)$ & 4 & 4 & 3 & $\mathbf{0}$ \\
\hline 14. Low backache $(0-4)$ & 2 & 2 & 1 & $\mathbf{0}$ \\
\hline TOTAL SCORE & 40 & 31 & 15 & $\mathbf{0}$ \\
\hline
\end{tabular}

Note -0 score - No; 1 score - Doubtful; 2 score - Mild; 3 score - Moderate; 4 score- Severe. 
ASSESSMENT OF SEVERITY -

\begin{tabular}{|c|c|}
\hline Scoring of Symptoms & Severity \\
\hline $0-13$ & Doubtful \\
\hline $14-26$ & Mild \\
\hline $27-39$ & Moderate \\
\hline $40-52$ & Severe \\
\hline
\end{tabular}

\section{ASSESSMENT OF RESULTS -}

Percentage of relief was assessed by comparing the total score before and after treatment and the relief was graded as under.

\begin{tabular}{|c|c|}
\hline Percentage Relief & Grading of Relief \\
\hline $\mathbf{0 \%}$ & No Improvement \\
\hline $1-25 \%$ & Mild Improvement \\
\hline $\mathbf{2 6 - 5 0 \%}$ & Moderate Improvement \\
\hline $\mathbf{5 1 - 7 5 \%}$ & Marked Improvement \\
\hline $\mathbf{7 6 - 1 0 0 \%}$ & Complete Improvement/Cured \\
\hline
\end{tabular}

\section{INTERVENTION:}

\begin{tabular}{|l|l|l|l|l|}
\hline Name of the drug & Dose & Anupana & Duration & Time \\
\hline Punarnavadi Guggulu & $\begin{array}{l}4 \text { Tablets (500 mg } \\
\text { each) Twice a day }\end{array}$ & Lukewarm water & $\begin{array}{l}\text { for consecutive 2 cycles } \\
\text { (from 1 } \mathbf{1}^{\text {st }} \text { day of menses } \\
\text { throughout the cycles) }\end{array}$ & After meal \\
\hline
\end{tabular}

\section{Follow up}

Every $2^{\text {nd }}$ day of menses upto 3 cycles (2 interventional and 1 observational cycle)

\section{OBSERVATION:}

The patient presented with a PMS score of 40 measured on the modified PMTS-OR Scale. After 1 month of treatment with Punarnavadi Guggul her score came down to 31 and 2 months later, her score was 15 . After one more month of observation without medicines, the patient had a score of zero. These findings indicate a significant relief in PMS. The carry forward effect of the medicine was evident from the zero score at the end of 3 months. Currently, ie. after 7 months of beginning treatment, the patient continues to be free from the symptoms of PMS.

\section{DISCUSSION:}

In the current case, suppression of urge for micturition, sedentary lifestyle and a tendency to overthinking and stress of academics seem to have contributed to the development of PMS. Eating South Indian food from hotels frequently was also a part of her lifestyle. Such food can contribute to Tridosha Prakopa.

As per many on going research studies, Premenstrual Syndrome is associated with Inflammation, Oxidative Stress and Antioxidant Status ${ }^{20}$

Punarnava has Vata Kapha Nashak, Shothghna, Rasayan. Mutral properties. 
The study by Meera Sumanth proved that Punarnava improved stress tolerance ${ }^{21}$

Anti-depressant activity ${ }^{1}$ of Punarnava was also proved in the study of Dinesh Dhingra()and it will also act on pathology caused by water retention such as swelling of extremities and,

Devdaru is known to posses - vatahara, amanashana, shophagna, tandrahara properties as per the various nighantus of Ayurveda. Studies have also proved the anxiolytic activity of devdaru through modulation of GABA levels. Its antidepressant activity has also been es the role of NO in depression and how Tinospora cordifolia exerts its beneficial effects in the patients of depression ${ }^{18}$. We can therefore infer that guduchi can effectively provide relief in the pschycosomatic symptoms of PMS.

Haritaki is known to posses properties like deepana, pachana, rochana, shothahara, kushthahara, shulahar. Therefore its helps to alleviate symptoms like headache and backache. Many subjects also experience symptomps like loss of appetite, indigestion and acne which are effectively relieved by haritaki.

It is also said to posses property of cleansing the manovaha strotas and the indriyas. A study by Yadavalli Chandra Shekhar proved that haritaki displayed significant anxiolytic activity in GABA proven. Anti-inflammatory and analgesic activity $^{27}$

Guduchi has Tridoshagna, Medohara, Mehaghna properties and is also Rasayana and Dhatu Agni Vardhak will help in treating Dhatwagnimandya and balancing of Tridoshas. Tinospora cordifolia commonly named as "Guduchi" has been reported for its strong free radical scavenging properties against superoxide anion $\left(\mathrm{O}_{2^{-}}\right)$, hydroxyl radicals $(\mathrm{OH}), \mathrm{NO}$, and peroxynitrite anion (ONOO-). Thus the present manuscript demonstrat

antagonist induced anxiety models in mice $^{22 .}$. The inhibition of GABAergic system is the most studied and proven pathologies that contributes to the PMS symptoms.

Anti-inflammatory ${ }^{24,} \quad$ Analgesic $^{24}$, Anxiolytic $^{25}$ properties of Hartaki cited below provide relief from PMS .

Guggulu will help in resolving shotha samprapti as well as in vata shamana. Erand tail will help in vata regulation. All the contents of Punarnavadi Guggulu have anti-inflammatory action that will probably act to break the water retention pathology and anti-oxidant $^{20}$ property (Rasayan), Hridya properties that will cure the mental symptoms and activity. And all the drugs having ushna veerya which will balance the vitiated Apana Vayu. Triphala kashaya has 
been used as bhavna dravya which is tridosh nashak and kleda-shamana, Shothaghna which will break the water retention pathology and Vatanulomana also.

Guggulu manages vata, and kapha, act on loss of appetite, indigestion, acne, constipation, ${ }^{29}$

Guggulu is antidepressant ${ }^{28}$ hence acts on GABAergic system. Anti-inflammatory ${ }^{30}$

Due to excessive consumption of junk food, vitiation of Apana Vayu, Vyana Vayu results in Dhatu Ksaya condition.

It is also responsible for pelvic congestion $^{14}$.

The centre researchers anticipated that the alleviation of hot flashes and also the symptoms associated with premenstrual syndrome are partially mediated by activity at estrogen receptors ${ }^{2}$ The most obvious among these involves aetiological role of fluctuations in ovarian steroids which influence neurotransmitters: serotonin, noradrenalin, and GABA. This explains impulse control, negative mood, aggression and irritability. Fluid and electrolyte retention are due to increased absorption/prolactin and sex steroid interaction with rennin-angiotensinaldosteron system $^{9}$

Junk foods being deficient in micronutrients like vitamin B6, calcium, magnesium and potassium, might also be responsible for triggering premenstrual symptoms. Premenstrual symptoms were also significantly high in girls who did not do regular physical activity Indulging in comfort foods like gooey chocolate bars, gulping down cups of coffee/tea or skipping meals because of feeling bloated is certainly not going to help. These will, in fact, aggravate the vulnerability of PMS symptoms.

Therefore Premenstrual symptoms are significantly high in girls who consume excessive junk food ${ }^{15}$.

\section{CONCLUSION:}

Punarnavadi Guggulu showed significant results in the present study. This drug helps in resolving the symptoms of PMS. This has proved that this classical preparation mentioned in shothadhikara is very effective in the treatment of PMS without any complications or adverse effects. Many studies have shown that both the ayurvedic formulations and modern modalities used as a treatment for PMS are antiinflammatory, so considering PMS with an inflammatory pathology and that's why believing Punarnavadi Guggulu will help in the management of symptoms PMS.

\section{REFERENCES:}

[1] Dinesh Dhingra, Evidence for involvement of the monoaminergic system in antidepressant-like activity of an ethanol extract 
of Boerhaavia diffusa and its isolated constituent, punarnavine, in mice

https://www.tandfonline.com/doi/fu $\underline{11 / 10.3109 / 13880209.2013 .870583}$

[2] Kimberly Ann Yonkers, MD, Prof. P M Shaughn O'Brien, MD, and Prof. Elias Eriksson, MD, Premenstrual syndrome Lancet. 2008 Apr 5; 371(9619): 1200-1210. doi: 10.1016/S0140-6736(08)60527 https://www.ncbi.nlm.nih.gov/pmc/ articles/PMC3118460/

[3] A Case Report On Effective Management Of Premenstrual Syndrome With Ayurveda http://ijaprs.com/index.php/ijapr/arti cle/view/691

[4] Ayurvedic Concept Of Premenstrual Syndrome With Special Reference To Pittavritta Vyana Vayu. BJOG - An International Journal Of Obstetrics And Gynaecology, Royal College Of Obstetricians And Gynaecologists Management of Premenstrual Syndrome, Green-top Guideline No. 48 November 2016, BJOG 2016; DOI: 10.1111/14710528.14260

RCOG Premenstural Syndrome.pdf

[5] Daniel M. Campagne, Ghislaine Campagne, the premenstrual syndrome revisited, European Journal of Obstetrics \& Gynecology and Reproductive Biology, Volume 130, Issue 1, 2007, Pages 4 -17, ISSN 0301-2115.

[6] Soo-Ho Chung ${ }^{1}$, Tae-Hee Kim ${ }^{1}$, Hae-Hyeog Lee ${ }^{1}$, Arum Lee ${ }^{1}$, Dong-Su Jeon ${ }^{1}$, Junsik Park ${ }^{1}$, Yesol $\mathrm{Kim}^{2}$, Premenstrual Syndrome and Premenstrual Dysphoric Disorder in Perimenopausal Women,Journal of Menopausal Medicine 2014; 20(2): 69-74. Published online: 27 August 2014

DOI: https://doi.org/10.6118/jmm.2 $\underline{014.20 .2 .69}$

[7] Andrea Rapkin, A review of treatment of premenstrual syndrome $\&$ premenstrual dysphoric disorder, Psychoneuroendocrinology, Volume 28, Supplement 3, 2003, Pages 39-53, ISSN 0306-4530, https://doi.org/10.1016/S03064530(03)00096-

[8] DC Dutta's Textbook of Gynaecology Enlarged \& Revised Reprint of Sixth Edition: November 2013 Seventh Edition: 2016 pg. no. 149

[9] Bharti Sharma, Subhash Sharma, Ayurvedic Concept Of Premenstrual Syndrome With Special Reference To Pittavritta 
Vyana Vayu, International Journal of Ayurveda and Pharma Research, IJAPR | June 2017 | Vol 5 | Issue 6 | page no. 96- 100. https://www.researchgate.net/public ation/341726061_Premenstrual_Syn drome and Its_Historical_Perspecti ve

[10] Malik, R., \& Bhat, M. D. A. (2018). The management of Premenstrual syndrome: A review. Bangladesh Journal of Medical Science, 17(1), 16-20. https://doi.org/10.3329/bjms.v17i1 .35273 .

https://www.banglajol.info/index.p $\underline{\mathrm{hp} / \mathrm{BJMS} / \mathrm{article} / \mathrm{view} / 35273}$

[11] Malik, R., \& Bhat, M. D. A. (2018). The management of Premenstrual syndrome: A review. Bangladesh Journal of Medical Science, 17(1), 16-20. https://pubmed.ncbi.nlm.nih.gov/2 $\underline{1802738 /}$

[12] Steiner M, Peer M, Macdougall M, Haskett R. The premenstrual tension syndrome rating scales: an updated version. J Affect Disord. 2011 Dec; 135(1-3):82-8. doi: 10.1016/j.jad.2011.06.058. Epub 2011 Jul 29. PMID: 21802738.

[13] Steiner, Meir \& Peer, Miki \& Macdougall, Mary \& Haskett,
Roger. (2011). The premenstrual tension syndrome rating scales: An updated version. Journal of affective disorders. 135 . 82-8. 10.1016/j.jad.2011.06.058.

https://www.researchgate.net/publi cation/51534030 The premenstru al tension_syndrome rating scale s An updated version

[14] Teixeira AL, Oliveira EC, Dias MR. Relationship between the level of physical activity and premenstrual syndrome incidence. Rev Bras Ginecol Obstet. 2013 May;35(5):210-4. [PubMed] b. Sr. Consultant Obstetrician and Gynaecologist, Fortis La Femme, http:/timesofindia.indiatimes.com/ life- Prashant Shinde Et Al: Effects Of Junk Food / Fast Food On Menstrual Health: A Review Study IAMJ: OCTOBER NOVEMBER, $2017 \quad 871$ style/health-fitness/diet/Foodsthat-ease-

PMSsymptoms/articleshow/14847 214.cms 02-02-2017)

[15] J. V. Joshi, $\underline{\text { S. N. Pandey, }}{ }^{1} \underline{\text { P. }}$ Galvankar, $^{2}$ and J. A. Gogate ${ }^{3}$ Prevalence of premenstrual symptoms: Preliminary analysis and brief review of management strategies. 
https://www.ncbi.nlm.nih.gov/pmc

/articles/PMC3139261/

[16] Akhila M, N, Vijayakumar \& Kannan VS. (2020). Effect Of Punarnavadi Kashayam And Aswagandha Choorna In Premenstrual Syndrome. International journal of Ayurveda and pharma research, 8(Supply1), $48-$

56.https://doi.org/10.47070/ijapr.v 8iSupply1.1625.

[17] Arif A Faruqui, Non Hormonal Management of Menstrual Cylce Irregularities, Journal of Gynecology and Womens Health Department of Pharmacology, Clinical Pharmacologist, A 504, Rizvi Mahal, India Submission: August 16, 2018; Published: September 07, 2018 Volume 11 Issue 4 - September 2018,ISSN2474-

7602https://juniperpublishers.com/ jgwh/

[18] Sezal, . and Walia, V. 2015. Review: Tinospora cordifolia in the Treatment of Depression. PharmaTutor. 3, 12 (Dec. 2015), 32-34. PRINT ISSN: 2394-6679 | E-ISSN: 2347-7881 https://www.pharmatutor.org/pdf download/pdf/Vol.\%203,\%20Issue
\%2012,\%20December $\% 202015, \%$

20PharmaTutor,\%20Paper-4.pdf

[19] Akhila M, N.Vijayakumar, Kannan VS. Effect of Punarnavadi KashayamAnd Aswagandha Choorna In Premenstrual Syndrome. International Journal of Ayurveda and Pharma Research. 2020;8(Suppl 1):48-56.

[20] Granda, D.; Szmidt, M.K.; Kaluza, J. Is Premenstrual Syndrome Associated with Inflammation, Oxidative Stress and Antioxidant Status? A Systematic Review of Case-Control and Cross-Sectional Studies. Antioxidants 2021, 10, 604. https://doi.org/10.3390/antiox 10040604

[21] Meera Sumanth and S.S. Mustafa, 2007. Antistress, Adoptogenic and Immunopotentiating Activity Roots of Boerhaavia diffusa in Mice. International Journal of Pharmacology, 3: 416-420.

https://scialert.net/fulltext/?doi=ijp.200 $\underline{7.416 .420}$

[22] Chandrasekhar Y, Phani Kumar G, Navya K, Ramya EM, Anilakumar KR. Tannins from Terminalia chebula fruits attenuates GABA antagonist-induced anxiety-like behaviour via modulation of 
neurotransmitters. J Pharm

Pharmacol.

2018

Dec;70(12):1662-1674.

doi:

10.1111/jphp.13007. Epub 2018

Sep 10. PMID: 30198561.

[23] Rapkin AJ, Akopians AL.

Pathophysiology of premenstrual syndrome and premenstrual dysphoric disorder. Menopause Int. 2012 Jun; 18(2): 52-9. doi: 10.1258/mi.2012.012014. PMID: 22611222.

[24] Seewaboon Sireeratawong, Kanjana Jaijoy, Parirat Khonsung, Noppamas Soonthornchareonnon, African journal of traditional, complementary and alternative medicine, Analgesic and antiinflammatory activities of the water extract from Terminalia chebula Rezt., Vol. 11 No. 6 (2014).

http://dx.doi.org/10.4314/ajtcam.v $\underline{11 \mathrm{i} 6.8}$

[25] Vasudevan Mani, Sultan Sajid, Syed Imam Rabbani, Abdulrahman Saud Alqasir, Hani Abdullah Alharbi, Abdullah Alshumaym, Anxiolytic-like and antidepressant-like effects of ethanol extract of Terminalia chebula in mice, Journal of Traditional and Complementary
Medicine, Volume 11, Issue 6,2021,Pages 493-502, ISSN 2225-4110, https://doi.org/10.1016/j.jtcme.202 1.04.003.

[26] D. Dhayabaran, E. Jeyaseeli Florance, K. Nandakumar and A . Puratchikody Anxiolytic and anticonvulsant activity of alcoholic extract of heart wood of Cedrus deodara roxb. in Rodents, Journal of Medicinal Plants Research Vol. 4(14), pp. 13741381, 18 July, 2010, DOI: 10.5897/JMPR10.140, ISSN 19960875 C)2010 Academic Journals http://www.academicjournals.org/J MPR

[27] Shinde UA, Phadke AS, Nair AM, Mungantiwar AA, Dikshit VJ, Saraf MN. Studies on the antiinflammatory and analgesic activity of Cedrus deodara (Roxb.) Loud. wood oil. J Ethnopharmacol. 1999 Apr;65(1):21-7. doi: 10.1016/s0378-8741(98)00150-0. PMID: 10350366.

[28] Kalshetti, Padmaja; Thakurdesai, Prasad; Alluri, Ramesh, Evaluation of Antidepressant Activity of Hydroalcoholic Extract of Commiphora Mukul (Engl.), 
Burseraceae in Mice, Journal of

Current Pharma Research;

Satara Vol. 5, Iss. 1, (Oct-Dec

2014): 1343-1350.

[29] Bhavprakash Nighantu with elaborated hindi commentary by Padmashri prof. K.C. Chunekar, edited by Dr. G.S. Pandey: edition of 2010: verse 32., page no- 204.

[30] Jayaraj A. Francis Bioactive Terpenoids and Guggulusteroids from Commiphora mukul Gum Resin of Potential AntiInflammatory Interest, Vol 1, issue 11, 24 November 2004 https://doi.org/10.1002/cbdv.2004 $\underline{90138}$ 